\title{
CIVIL LIABILITY FOR PRIMARY SECURITIES DISTRIBUTIONS IN THE UNITED STATES AND THE UNITED KINGDOM
}

\author{
ROBERT E. KOHN* \\ I \\ INTRODUCTION
}

Company law in the United Kingdom and securities regulation in the United States have developed over the past six decades in response to rapidly changing economic, political and social circumstances. Without trying to analyze these circumstances, this article will identify the main features of the regulation of primary securities distributions' in the two countries and compare their treatment of civil liability. The article will then try to characterize the policy objectives of these features of regulation and to identify some economic and political costs of achieving them.

\section{OfFerings in the United States}

\section{A. Registered Offerings}

The sale of corporate securities to the public in the United States is principally regulated under the Securities Act of $1933^{2}$ ("Securities Act"). Unless an appropriate exemption applies, the Securities Act requires the issuing company to file with the Securities and Exchange Commission ("SEC") a registration statement whose contents are prescribed by statute and by rule. When registration is required, the statute limits the timing and manner of selling efforts, in part by requiring the delivery to every purchaser of a prospectus whose contents are also prescribed. ${ }^{3}$ In addition, section 11

\footnotetext{
Copyright $\odot 1992$ by Law and Contemporary Problems

* Judicial Law Clerk, United States Court of Appeals for the Eleventh Circuit. A.B. 1989, J.D. 1992, Duke University.

The author is indebted to the Special Editor of this volume, Professor James D. Cox of Duke University, for his inspiration and tireless patience in the preparation of this article, and for his insight and suggestions in reviewing an earlier draft; and to the late Professor F. Hodge O'Neal of Washington University for his guidance and assistance at the beginning of the author's legal career.

1. Primary distributions involve the sale of securities by companies to the investing public, usually in exchange for cash; they should be distinguished from secondary transactions involving sales between investors, which do not directly increase the capital available to issuing companies.

2. 15 USC $\S \S 77 a-77$ aa (West Supp 1990). Further citations of this statute will refer to its original section numbers, without stating the corresponding location in the U. S. Code.
}

3. Securities Act $\S \S 5,10$. 
of the Act imposes civil liability upon the issuer and others for material misrepresentations and omissions in the registration statement. ${ }^{4}$

1. Mechanics of Registration. One innovation of the Securities Act was the creation of a waiting period (at least twenty days long) between the time of filing a registration statement and the time when it becomes effective. Section 5 makes it unlawful to offer to sell or buy the securities before the statement is filed. ${ }^{5}$

Section 5 also prohibits the sale or delivery of securities during the postfiling waiting period. However, the underwriters (or anyone else) may make offers to sell the securities during this time, and the SEC may shorten the period by "accelerating" the effective date. ${ }^{6}$

The parties to the underwriting agreement, including the issuer and the members of the underwriting syndicate, are free to bind themselves before the effective date. ${ }^{7}$ But they usually defer executing a binding agreement obligating the underwriters to carry out the offering, preferring instead to proceed on the basis of a "letter of intent." This arrangement typically commits the issuer to using the underwriters' services, and to paying for some or all of their expenses in preparing the offering. Although the precise terms of the letter of intent are matters for negotiation, the offering's final terms usually are not settled until immediately before the distribution begins. ${ }^{8}$

Those large and established companies that are eligible to register an offering on the abbreviated Form S-3 can mitigate market risk by making a delayed or continuous offering under SEC Securities Act Rule 415. Such a transaction involves the pre-registration of securities to be taken "off the shelf" later and offered at the then-current market price (or at a small discount), in uncertain volume or at undetermined points in time. ${ }^{9}$ The rule can be used in a variety of transactions, but equity offerings into a trading market must employ a registration statement naming at least one underwriter. ${ }^{10}$ This requirement prevents large and sophisticated companies from offering securities without the steadying hand and watchful eye of

4. Id. $\$ \S 6(a), 11(a)$. The SEC in its rules and forms uses the word "material" to mean "those matters to which there is a substantial likelihood that a reasonable investor would attach importance in determining whether to purchase the security ...." Securities Act Rule 405, 17 CFR $\$ 230.405$ (1992).

5. In this context, the SEC and the courts have broadly construed the phrase "offer to sell" to include any communication intended to stimulate an interest in the securities or their issuer. But with respect to certain carefully drawn exceptions to this principle, see SEC Securities Act Rules 135, 135A, 135B, 138, 139, 17 CFR $\$$ 230.135, 230.135a, 230.135b, 230.138, and 230.139, respectively.

6. The earlier practice of soliciting the SEC's "acceleration" of the effective date to allow the issuer to fix the price at which securities were to be sold has been abandoned in offerings for cash. Securities Act Rules 430A, 497(b), 497(h), 17 CFR $\$$ 230.430A, 230.497(b), and 230.497(h), respectively.

7. See Securities Act $\S 2(3)$.

8. See John S. D'Alimonte, The Letter of Intent and the Basic Structure of an Offering, in Kenneth J. Bialkin \& William J. Grant, eds, Securities Underwriting: A Practitioner's Guide 85, 86-87, 96-97 (Practising Law Institute, 1985).

9. See 48 Fed Reg 52889 (Nov 17, 1983).

10. SEC Securities Act Rule 415(a)(4)(iii), 17 CFR $\$ 230.415$ (a)(4)(iii). 
market professionals who are subject to liability under section 11, with its associated due diligence obligations, discussed below.

2. Liability for Offerings of Registered Securities. Section 11 of the Securities Act imposes strict liability upon issuers for material misrepresentations or omissions in the registration statement. " Beyond issuers, section 11 further imposes liability upon directors, principal officers, ${ }^{12}$ underwriters, ${ }^{13}$ and professionals whose statements are accurately included in the registration statement. But these parties may escape liability by establishing a "due diligence" defense.

Section 11 does not require the plaintiff to show privity of contract with the defendant or any other participant in the distribution, although the investor must show that her securities were initially offered under the registration statement in question. ${ }^{14}$ Moreover, liability usually does not require reliance upon the alleged misstatements, ${ }^{15}$ although the plaintiff investor must not actually have known the truth. ${ }^{16}$ Even when she must show reliance, "such reliance may be established without proof of the reading of the registration statement." 17 Thus, liability covers the cumulative loss suffered by each successive purchaser of the registered securities, few of whom will need to show actual reliance upon the alleged falsehood.

Subsection (e) sets out the measure of damages in a section 11 claim. In general, the plaintiff recovers the diminution in the securities' market value caused by the misrepresentation or omission. The defendant bears the burden of showing the absence of legal causation. ${ }^{18}$ In calculating this loss, the plaintiff's original purchase price is deemed not to exceed the price at which the securities were offered to the public. The statute further limits each underwriter's individual liability to "the total price at which the securities

11. Securities Act $\S \S 6(a), 11(a)(1)$. A cause of action arises "[i]n case any part of a registration statement, when such part became effective, contained an untrue statement of a material fact or omitted to state a material fact required to be stated therein or necessary to make the statements therein not misleading." Securities Act \$11(a).

12. The issuer's principal executive, financial and accounting officers are all required to sign the registration statement. Securities Act $\S 6(a)$. As signatories they are potentially liable pursuant to $\$ 11(\mathrm{a})(1)$.

13. It bears noting that an "underwriter" under the Securities Act need not be a market professional or even have an agreement with the issuer. "[A]ny person who has purchased from an issuer with a view to, or offers or sells for an issuer in connection with, the distribution of any security" is an underwriter. Securities Act $\S 2(11)$. For purposes of this definition of underwriter, a person who controls the company can be considered an "issuer." Thus, the statute imposes disclosure obligations upon anyone who facilitates a public "distribution" by an issuer or one of its principals. See SEC v Chinese Consol. Benevolent Ass'n, 120 F2d 738, 740-41 (2d Cir 1941).

14. Barnes v Osofsky, 373 F2d 269 (2d Cir 1967); In re Elscint, Lid. Securities Litig., 674 F Supp 374 379, 382-83 (D Mass 1987).

15. The plaintiff must show reliance only if she "acquired the security after the issuer has made generally available to its security holders an earning statement covering a period of at least twelve months beginning after the effective date of the registration statement." Securities Act $\$ 11$ (a). See also Securities Act Rule 158, 17 CFR \& 230.158.

16. Securities Act $\$ 11(\mathrm{a})$.

17. Id.

18. See Akerman v Oryx Communications, Inc., 810 F2d 336, 340-41 (2d Cir 1987). 
underwritten by him . . . were offered to the public."19 Section 12 imposes a similar limitation on the measure of damages in its cause of action, to be discussed below, by confining the class of potential plaintiffs to include only those who purchased directly from or through the defendant. ${ }^{20}$

a. Due diligence. Other than the issuer, each potential defendant under section 11 may escape liability by establishing a "due diligence" defense. There are two types of due diligence. Under the most lenient standard, a defendant may rely upon representations included in the registration statement by an "expert" (other than himself) who has consented to be named in the filing.

An expert is a person whose "profession gives authority to a statement by him." 21 The defendant can establish his defense if "he had no reason to believe and did not believe" that the expert's statement was untrue or that it omitted a material disclosure. ${ }^{22}$ Thus, for example, the issuer's directors or underwriters may rely upon a financial statement that an accountant has certified in the registration statement, provided they do so with objective good faith.

A more rigorous due diligence standard applies when the alleged misrepresentation did not appear in an expert's statement. This standard requires the defendant to show that she "had reasonable grounds to believe, and did believe ... that the statements were true and that there was no omission to state a material fact required to be stated therein or necessary to make the statements . . not misleading." 23 Thus, the defendant must not permit a registration statement to become effective if to do so would be negligent.

19. Securities Act $\$ 11$ (e) (emphasis added). There is an exception to this limitation of liability, applicable to an underwriter who "shall have knowingly received from the issuer for acting as an underwriter some benefit, directly or indirectly, in which all other underwriters similarly situated did not share in proportion to their respective interests in the underwriting." Id. One author has observed that "[m]anaging underwriters do receive an extra fee, but they have routinely evaded unlimited liability by arranging for the syndicate rather than the issuer to pay this fee." Note, Expanding the Liability of Managing Underwriters Under the Securities Act of 1933, 53 Fordham L Rev 1063, 1071 (1985) (authored by Dana B. Klinges) (citations omitted). Even if the management fee were considered "indirect[]" compensation by the issuer, the lead underwriter might still argue that it is not "similarly situated" with other syndicate members because they have delegated authority to conduct due diligence investigations. See text accompanying note 34 .

20. The Securities Act statute of limitations (applicable to claims under $\S \S 11$ and 12) appears in $\S 13$. It bars suits under $\$ \S 11$ and 12(2) after one year from the plaintiff's discovery of the defective disclosure, or from the time when "such discovery should have been made by the exercise of reasonable diligence." Suits under $\$ 12(1)$ alleging noncompliance with formal prospectus and registration requirements must be filed within one year from the date of the violation.

Section 13 further provides a three year statute of repose. For claims under $\S \S 11$ and $12(1)$, the clock starts when the securities were first "bona fide offered to the public." For suits alleging defective disclosure under $\$ 12(2)$, whether or not the offering was exempt from registration, the clock starts at the time of sale. This delayed statute of repose represents the principal usefulness of $\$ 12(2)$ for plaintiff investors who buy during registered distributions, especially those offered from the shelf.

21. Securities Act \& 11(a)(4).

22. Id at $\$ 11(\mathrm{~b})(3)(C)$.

23. Id at $\$ 11(\mathrm{~b})(3)(\mathrm{A})$. 
In addition, as a separate element of her defense, the defendant who cannot rely upon an expert must show that she made a "reasonable investigation." 24 Judicial decisions state that the reasonableness of an investigation will depend in part upon the duration and character of the defendant's relationship with the issuer, although mere reliance on the representations of management is never sufficient. ${ }^{25}$ The court will consider whether the defendant is a corporate "insider" (such as an officer or managing director of the issuer) or an "outsider" (such as an independent director or an underwriter), and whether an outsider possesses special financial expertise or has participated actively in the distribution. ${ }^{26}$

Although the courts apply a "sliding scale of responsibility, based on what can realistically be expected of the particular defendant," ${ }^{27}$ there will be no defense without some investigation beyond reliance upon the statements of the issuer's management. The early case of Escott v. BarChris Construction Corp. ${ }^{28}$ suggested that due diligence required a full audit of the transaction, including independent examination of underlying written records. Later, however, the court in Feit v. Leasco Data Processing Equipment Corp. ${ }^{29}$ seemed to adopt a slightly more relaxed standard.

Feit considered whether two underwriters promoting an exchange of the issuer's securities in a tender offer for another company's stock had adequately investigated the target's finances. The target possessed a fund of capital exceeding its operational requirements. Because the issuer contended that estimates of this surplus ranging from $\$ 50$-125 million were "unreliable," the registration statement had not disclosed the existence of the fund. ${ }^{30}$ The target's president testified that he easily could have made a more precise estimate on the basis of his detailed knowledge of the company's position, and the court found that he probably would have complied with a request by the tenderer that he provide a figure. However, the issuer had falsely told the underwriters that the target's management would have refused such a request, even after the target had actually accepted the takeover. ${ }^{31}$ Despite their failure to inquire directly of target management after the target agreed to adopt a "neutral" stance regarding the offer, the court concluded that the underwriters had "just barely" met their due diligence obligations by reviewing documents that clearly showed the target's earlier hostility to the

24. Id.

25. See Escott v BarChris Constr. Corp., 283 F Supp 643, 688-89, 696-97, 702-03 (SD NY 1968).

26. See, for example, Laven v Flanagan, $695 \mathrm{~F}$ Supp 800, 812 (D NJ 1988); Feit v Leasco Data Processing Equip. Corp., 332 F Supp 544, 578 (ED NY 1971); BarChris, 283 F Supp at 689-92.

27. James D. Cox, Robert W. Hillman \& Donald C. Langevoort, Securities Regulation: Cases and Materials 630 (Little Brown, 1991).

28. 283 F Supp 643 (SD NY 1968).

29. 332 F Supp 544.

30. Feit, 332 F Supp at 553-54.

31. Id at 561-62. 
transaction, and relying on the issuer's statement that management continued in refusing to provide information. ${ }^{32}$

One might have expected that the underwriters' liability would motivate each of them to inquire beyond the face of the registration statement, and to ensure that its contents were accurate. In practice, syndicate members in the United States generally pay a fee to the managing underwriter and rely on its investigation of the truthfulness and completeness of the filing. (Payment of this fee may take the form of an allowance for a larger portion of the gross underwriting commission). Having designated the lead underwriter as their agent for purposes of investigating the issuer, the syndicate will possess (or lack) a defense to the same extent that the lead underwriter can (or cannot) evade liability. "The underwriting syndicate members therefore sink or swim with the lead underwriter in the usual case." 33

Syndicate members formalize this practice by delegating powers of attorney to the lead underwriter. Such arrangements eliminate repetitive investigations. The syndicate relies on the lead underwriter to carry out the investigation because its members know that the lead underwriter faces similar liability as an incentive for thoroughness. Although the manager is potentially liable only for the price of its portion of the issue, it has a complementary interest in preserving its reputation in the financial community. These arrangements provide sufficient assurance of thoroughness that syndicate members usually waive any claims they might have against the lead underwriter for negligence or disobedience as their agent in carrying out the investigation.

In order to avoid the necessity of establishing the more rigorous due diligence defense, the underwriters and the issuer's management employ experts to certify as much of the registration statement as possible. They also obtain contractual undertakings from the experts to perform their investigations thoroughly. Naturally the experts require a fee in exchange for their investigation, and for their assumption of exposure to liability in the event that they should fail to discover a material inaccuracy. The underwriting syndicate usually pays these fees through the lead underwriter and funds them with the gross underwriting commission. This process of contractually allocating potential liability approximates the role of a limited indemnification agreement favoring the potential defendants who, in good faith, seek comfort from the expert. Yet it differs from conventional indemnification contracts because the expert defendant has an independent due diligence defense, whose proof offers a substantial incentive for investigation and disclosure. ${ }^{34}$

32. The court also noted the syndicate's "thorough review of all available financial data," examination of auditors' reports of the two companies, and study of the issuer's corporate minutes, records and major agreements. Id at 582-83.

33. In re Consumers Power Co. Securities Litig., 105 FRD 583, 612 (ED Mich 1985).

34. See generally Helen S. Scott, Resurrecting Indemnification Agreements: Contribution Clauses in Underwriting Agreements, 61 NYU L Rev 223 (1986). 
b. Integrated disclosure and shelf offerings: due diligence and updated information. Other than the ability to make delayed equity offerings at market under Rule $415,,^{35}$ a principal benefit to the issuer of registering on Form S-3 is that periodic reports filed with the SEC under the Securities Exchange Act of $1934^{36}$ ("Exchange Act") may be incorporated into the registration statement by reference. The prospectus delivered to investors must expressly refer to these reports in a general way, but it need not reproduce or attach them: Only companies having large public investment and control, along with certain indicia of financial soundness, may qualify to use Form S-3.

Form S-2 also permits the incorporation of Exchange Act reports by reference. This abbreviated registration statement is available to all issuers who have been subject to Exchange Act periodic disclosure requirements for three years, and who have the same signs of financial soundness required for the use of Form S-3. Unlike offerings registered on Form S-3, those using Form S-2 must reproduce or attach the incorporated reports with the prospectus. Whether the issuer uses Form S-2 or Form S-3, the registration statement and the prospectus must also state "all material changes in the registrant's affairs" since the filing of the incorporated or attached reports. ${ }^{37}$

Reports incorporated by reference become part of the registration statement. As such, they may become the basis for liability under section 11 . They are also part of the prospectus, and thus present a basis for liability under section 12(2), discussed below. However, in the typical case, persons who will become potential defendants when the offering begins (those listed in section 11(a), and "sellers" under section 12) do not foresee the exact circumstance of the future offering at the time when they are preparing the Exchange Act reports. Facts which might not seem material when the defendants are preparing the annual report may become important in the context of the later offering. All such changes in the issuer's "affairs" must also be disclosed when the registration statement is filed.

Parallel with section 11 liability for misrepresentations in the registration statement, Exchange Act section 10(b) and its Rule 10b-5 impose liability for misrepresentations in Exchange Act filings. ${ }^{38}$ Because the mens rea standard of liability in a Rule $10 \mathrm{~b}-5$ civil action is scienter, rather than mere lack of due diligence, ${ }^{39}$ there is little occasion for a plaintiff to rely on the rule when he can take advantage of section 11.40 Moreover, the $10 \mathrm{~b}-5$ plaintiff bears the burden of proving scienter and causation, whereas a section 11 defendant must establish his due diligence or the lack of causation as an affirmative

35. See text accompanying notes 9-10.

36. 15 USC $\$ \$ 78 \mathrm{a}-78 l l$ (West Supp 1990).

37. Securities Act Form S-3 Item 11(a), 17 CFR \& 239.13 (1992), 47 Fed Reg 11457 (Mar 16, 1982); SEC Securities Act Form S-2 Item 11(a)(4), 17 CFR $\S 239.12,47$ Fed Reg 11452 (Mar 16, 1982); SEC Securities Act Rel No 33-6383, 47 Fed Reg 11380 (Mar 3, 1982).

38. 17 CFR \& 240.10b-5 (1992).

39. See Ernst E Ernst v Hochfelder, 425 US 185, 212 (1976).

40. See, for example, Huddleston v Herman \& MacLean, 640 F2d 534, 544-45 (5th Cir 1981), rev'd in part on other grounds, 459 US 375 (1983). 
defense. Therefore the investigative incentive that the issuer and its management face when preparing the Exchange Act reports appears to be weaker than the section 11 incentive during the pre-effective period of a typical registration statement. This disparity reveals the dominant principle of section 11 liability: deterrence of defective disclosure rather than mere compensation for investors, ${ }^{41}$ in part as a device to create (and continue) public confidence in securities markets. ${ }^{42}$ These objectives may suffer because of the simplicity of preparing an integrated registration statement.

The problem of incorporating earlier Exchange Act reports in a subsequent Form S-2 or S-3 registration statement under the Securities Act is especially acute for underwriters, who may have had no contact at all with the issuer while it prepared the reports. In recognition of the underwriter's dilemma, the SEC's Securities Act Rule 176 states that the role of an underwriter and the availability of information to him are "relevant circumstances," for purposes of assessing the reasonableness of his due diligence investigation. ${ }^{43}$ It is also relevant "[w]hether, with respect to a fact . . . incorporated by reference, the particular [defendant] had any responsibility for the fact . . . at the time of the filing from which it is incorporated." 44 By indicating that these are "relevant circumstances," the Commission has recognized the policy conflict between strict due diligence and the cost savings of integrated disclosure, but has not provided very specific guidance to the courts in striking a balance. ${ }^{45}$

When the sale occurs some time after the effective date of the registration statement, as typically occurs in a shelf offering, newer information may be disclosed in three ways:46 (1) incorporation by reference of subsequent Exchange Act reports if registered on Form S-3 (as required in a shelf offering), (2) post-effective amendment of the registration statement accompanied by the printing of a new prospectus, or (3) preparation of a "sticker" attached to the old prospectus without the need for post-effective amendment of the registration statement. ${ }^{47}$

The inclusion of new information in an integrated registration statement (using Form S-2 or S-3) starts a new statute of limitations period for securities offered by the issuer after the information is filed. ${ }^{48}$ If added only to the

41. See, for example, Feit v. Leasco Data Processing Equip. Corp., 332 F Supp 544, 567; Kennedy $v$. Josephthal E' Co., [1982-1983 Transfer Binder] Fed Secur L Rptr (CCH) ף 99,204 at 95,821-22 (D Mass May 9, 1983).

42. See Joel Seligman, The Transformation of Wall Street: A History of the Securities and Exchange Commission and Modern Corporate Finance 53-54 (Houghton Mifflin, 1982).

43. Securities Act Rule 176(g), 17 CFR $\$ 176(\mathrm{~g})$.

44. Securities Act Rule 176(h), 17 CFR $\$ 176(\mathrm{~h})$.

45. The Commission has provided some suggestions to underwriters in meeting their due diligence obligations. See 48 Fed Reg 52889 (Nov 17, 1983).

46. See generally Roger D. Blanc, Special Considerations Relating to Shelf Offerings, in Bialkin \& Grant, eds, Securities Underwriting at 381 (cited in note 8).

47. See Securities Act Rule 424(c), 17 CFR $\$ 424(c)$.

48. Securities Act Reg S-K Items 512(a)(2), 512(b), 17 CFR $\$ \S 229.512(a)(2), 229.512(b)$ (1992). 
prospectus, the new information implicates only section 12(2) (and Rule 10b5) and does not create a new limitations period for section 11 claims.

Post-effective amendments to the registration statement itself are required for material information about the plan of distributing the securities, other than the price and related details. ${ }^{49}$ For registration statements that do not use Form S-3, and which thus do not continue automatically to accrue new information by reference upon the filing of each new Exchange Act report, amendment to include new reports is required before a sale may be completed only if the sale occurs nine months after the effective date, or when the old information has become more than sixteen months old, whichever is later. ${ }^{50}$ Failure to make such an amendment constitutes a formal defect giving rise to strict liability under section 12(1) of the Securities Act. In addition, the issuer must always amend the registration statement if there has been a "fundamental change" in the information (as opposed to a merely "material" change). ${ }^{51}$

\section{B. Civil Liability Irrespective of Registration: Section 12}

As we have seen, the Securities Act provides issuers and their associates with several possible exemptions from registration. Section 12(1) makes a "seller" strictly liable for promoting an unregistered sale, absent an exemption.

Section 12(2) imposes liability upon a seller who himself makes any material misrepresentations or omissions, whether or not an exemption from registration is available. ${ }^{52}$ This is so because section 12(2) liability arises only when the defendant "offers or sells a security . . . by means of a prospectus or oral communication," 53 whereas section 11 imposes liability upon a fixed class of defendants for any misstatement in the registration statement, ${ }^{54}$ without regard to their participation in the selling effort or the preparation of disclosure documents.

The remedy under section $12(2)$ is the same as under section 12(1), rescission or similar damages. As in the 12(1) case, only "the person purchasing [the] security from [the defendant]" has standing to sue. ${ }^{55}$ The privity requirement for a 12(2) cause of action appears to have the same definition provided by the Supreme Court in Pinter $v$. Dahl ${ }^{56}$ for a section

49. For example, a change from "best efforts" to "firm commitment" underwriting requires disclosure through post-effective amendment. 46 Fed Reg 42001 (Aug 6, 1981).

50. Securities Act $\S 10(a)(3)$; SEC Securities Act Reg S-K Item 512(a)(1)(i), 17 CFR $\S 229.512(\mathrm{a})(\mathrm{l})(\mathrm{i})$.

51. SEC Securities Act Reg S-K Item 512(a)(1)(ii), 17 CFR § 229.512(a)(1)(ii). See 46 Fed Reg 42001 (Aug 6, 1981); 47 Fed Reg 11380 (Mar 3, 1982).

52. Liability arises when "[a]ny person ... [o]ffers or sells a security . . by means of a prospectus or oral communication, which includes an untrue statement of a material fact or omits to state a fact necessary in order to make the statements, in light of the circumstances under which they were made, not misleading ...." Securities Act $\S 12(2)$.

53. Securities Act $\$ 12(2)$.

54. See note 11.

55. Securities Act $\S 12$.

56. 486 US 622 (1988). 
12(1) suit: A person who transfers title to the securities, or one who directly solicits a sale ${ }^{57}$ and who is motivated in part by his own financial interests or those of the transferor, can be sued by an investor who purchased from him. ${ }^{58}$

Like plaintiffs under section 12(1), the aggrieved purchaser under section 12(2) need not prove reliance upon the alleged defect; but there must be some relation between the content of the misstatements and the alleged loss. 59 Thus, the plaintiff must show a form of "loss causation." The seller, including an issuer, may invoke a due diligence defense similar to the one provided by section $11 .{ }^{60}$ When raised by an underwriter, the defense requires proof of a reasonable investigation without reliance upon the statements of experts. ${ }^{61}$

\section{Summary of Liability Provisions}

The combined effect of sections 11 and 12(2) may be summarized as follows. In a private placement or other exempt transaction, a "seller" will be liable to his purchaser for any loss caused by his own material misrepresentations. Consequently, a defendant's liability is limited to the price of the securities he sells, and can be predicated only on statements he actually makes.

In a registered public distribution, the issuer, its underwriters, and its corporate insiders are liable to the investing public at large for their cumulative loss caused by any materially defective disclosure in the offering documents, or some limited omissions of new information after the effective date. Yet each underwriter's aggregate liability is limited to the price of securities underwritten by him, while each investor is deemed to have purchased the securities at a price no higher than the public offering price.

All defendants in exempt transactions may invoke a reasonable investigation as a defense, but may not rely on the statements of experts to establish the defense per se. In a registered offering the issuer has no defense, other than the absence of legal causation, but other defendants who may invoke their own due diligence are further shielded by their reliance upon the statements of experts. Most plaintiffs need show no reliance upon the alleged misrepresentations, whether or not the offering was registered.

57. Attorneys, accountants, and others who actively participate in the transaction do not become "sellers" unless they also join the selling effort by actually communicating with offerees. Id at 650-52 nn26-27.

58. No liability is created when an offeror's misrepresentations induce the plaintiff to abstain from purchasing. Id at 644. Compare Blue Chip Stamps v Manor Drug Stores, 421 US 723, 730-31 (1975)(Rule 10b-5 grants no cause of action unless plaintiff is either a purchaser or a seller of securities).

59. See, for example, Austin v Loftsgaarden, 675 F2d 168, 176 (8th Cir 1982); Sanders v John Nuveen E Co. [Sanders IV], 619 F2d 1222, 1225 (7th Cir 1980).

60. The defendant must "sustain the burden of proof that he did not know, and in the exercise of reasonable care could not have known, of [the] untruth or omission." Securities Act $\$ 12(2)$.

61. Sanders $I V, 619$ F2d at 1228, cert denied, 450 US 1005 (1981) (Powell and Rehnquist, IJ dissenting from denial of certiorari). 
III

\section{The UNITED Kingdom}

As a practical matter, the most important difference [between the liability exposure of U.S. and U.K. market professionals] may be one of legal "ethos"-the willingness of investors to bring lawsuits and the receptivity of courts to these suits. Furthermore, the availability of contingent fee arrangements, the American rule with respect to the awarding of attorneys' fees, and the greater ease of bringing derivative suits and class actions all militate in favor of bringing investors' suits in the United States. In these respects, an American firm is far more exposed to liability in civil suits than a British firm. ${ }^{62}$

The British judicial ethos is further illustrated by commentators' criticisms of "notoriously litigious international securities and finance houses" which "bear as much resemblance to Aunt Agatha-who [legislation] was designed to protect-as a local market apple stall bears to a supermarket chain." 63 In the past, courts have been reluctant to find liability in the few cases brought before them by private sector investors.

Yet the British system does not lack effective judicial enforcement of the securities laws. As discussed below, the courts have responded generously to claims by regulators who sue for civil enforcement of laws and regulations concerning proper disclosure and fraud.

\section{A. Institutional Background}

British law governing corporate capital formation is in a state of flux as provisions of the Financial Services Act 1986 ("FSA") are gradually brought into force and modified. ${ }^{64}$ The complex institutional structure imposed by the FSA has been subject to near-continual modification, and further reforms have been proposed.

Equity solicitations of any size in the United Kingdom take place under the regulatory auspices of the London Stock Exchange. ${ }^{65}$ The Exchange governs all trading in "listed" and "unlisted" securities 66 over the only organized market for equity securities, the Stock Exchange Automated Quotations

62. Norman S. Poser, International Securities Regulation: London's "Big Bang” and the European Capital Markets 300 (Little Brown, 1991)

63. Section 62-Financial Services Act, 137 New L J 1034 (Nov 6 1987). 740 .

64. The most significant provisions became effective in 1988 . Statutory Instrument 1988 No

65. The Exchange was formerly constituted as the International Stock Exchange of the United Kingdom and the Republic of Ireland Limited.

66. The distinction between "listed" and "unlisted" securities depends principally on the size of the issuer and certain features of its securities that are immaterial for purposes of this article. Although formally regulated under different Parts of the FSA, the Act's provisions in substance duplicate the regulation of both classes. Part V, relating to unlisted securities, is the only British legislation requiring preparation of a "prospectus" as the disclosure document, rather than a "listing particulars." When brought into force, Part V will implement the EEC Council Directive 89/298, OJ L (1989) 124/8 ("Prospectus Directive"). See generally Prospectus Directive, 87 Law Society's Gazette 3 (Nov 7, 1990).

Accordingly, we shall consider listed securities only. 
("SEAQ") system.67 Non-equity securities may also be listed on the Exchange, but almost all debt trading in the United Kingdom (other than trading in British Government bonds) takes place by wire. ${ }^{68}$

The Exchange's authorization to regulate trading derives from section 142(6) of the FSA. It has no legal authority to regulate the business practices of its members apart from trading. The Securities and Futures Association ("SFA"), one of several "self-regulating organizations" ("SROs") deriving legal authority from recognition by the Securities and Investment Board ("SIB"), has power to regulate the business affairs of its corporate and individual members. ${ }^{69}$ The SIB is a quasi-official body that in turn derives legal authority from a delegation of power by the Secretary of State for Trade and Industry, the head of the Department of Trade and Industry ("DTI"), pursuant to the FSA. ${ }^{70}$

Membership in a recognized SRO is required in order to engage in the "investment business."71 The SFA is the SRO with authority over persons who trade in domestic and international equities, domestic and international debentures and bonds, U.K. government securities, options and financial futures. Thus, SFA rules are important sources of law.

Like the Eurobond market, the British equity market also caters to institutional investors, although there is some significant participation by individuals. As in the United States, approximately twenty percent of the population owns corporate shares. ${ }^{72}$ This "investing class" has been created largely through recent privatization programs in which the government has sold state-owned industries to the public, ${ }^{73}$ and the accompanying enactment of favorable taxation provisions for the individual investor. ${ }^{74}$

67. SEAQ is an electronic market similar to the National Association of Securities Dealers Automated Quotations ("NASDAQ") in the United States.

68. There is an international debt market centered in London called the Eurobond market, an informal designation that simply signifies a market for bonds traded in Europe between institutional investors. About $70.80 \%$ of Eurobond primary distributions and secondary trades take place in London. Eurobond debt securities traded among institutions are technically not required to be listed, but compliance with currency regulations of other EC countries usually mandates Exchange listing. Poser, International Securities Regulation at 22-23 (cited in note 62).

69. The SFA was created on April 1, 1991 by the merger of The Securities Association ("TSA") and the Association of Futures Brokers and Dealers. The International Stock Exchange and the TSA shared the same professional staff and were closely affiliated. See Id at 35.

70. FSA $\S \S 31(4), 86(1), 87(1), 114(5)$; Statutory Instrument 1987 No 942 , art 3.

71. FSA $\$ 3$

72. Poser, International Securities Regulation at 75-76 (cited in note 62); Joyce Kalcich, ed, New York Stock Exchange Fact Book 52 (NY Stock Exch, 1985).

73. See, for example, Steven L. Wolfram \& Bruce C. Bennet, Multinational Offerings: A United States Perspective After British Telecom, British Gas and British Airways, 1987 Colum Bus L Rev $339,345$.

74. International Stock Exchange, Official Yearbook 1987-1988, at 9 (Stockton Press, 1988) Despite the large number of individual investors, very few of them have large portfolios. Only $44 \%$ own shares in more than one company, while $14 \%$ have a portfolio of more than three stocks. Poser. International Securities Regulation at 75 (cited in note 62). 


\section{B. Regulatory Framework}

Before a security may be listed, it must be approved by the Council of the Exchange. ${ }^{75}$ More precisely, a security may not be admitted to the Official List of the Exchange until an application for listing is submitted and approved according to the Exchange's "Yellow Book" (officially titled Admission of Securities to Listing) ${ }^{76}$ and subject to any other condition that the Exchange may impose on the particular issuer. ${ }^{77}$

The listing process is the principal system for regulating primary offerings of equity and debt securities. It mirrors the approach taken in the United States by the Securities Act in several important ways. First, a transactionspecific disclosure obligation and scrutiny by regulatory authorities are implicated only when a "listing particulars" document is required to be published. Absent an exemption, ${ }^{78}$ securities may not be listed (and therefore may not be traded on SEAQ) until the listing particulars is published; ${ }^{79}$ this document may not be published unless approved by the Council of the Exchange, ${ }^{80}$ under delegation from the DTI. ${ }^{81}$ Recall that SEAQ is the only organized equity market, and the only market available to individual investors. Eurobond issues are almost uniformly listed on the Exchange as well. Thus, like the registration statement in U.S. law, the listing particulars is the major disclosure document for public offerings. It is through the listing particulars that the authorities monitor the issuer's disclosure. ${ }^{82}$

The second similarity to U.S. regulation appears in section 150 of the FSA, which imposes upon "responsible persons" civil liability for offers of listed securities when the listing particulars (or supplementary listing particulars) contains "any untrue or misleading statement or omi[ts] . . any matter required to be included." As it happens, this provision of the statute has not yet been presented to the courts for application. The absence of such suits is

75. The Council's powers are exercised by the Committee on Quotations, "advised by the Quotations Department." London Stock Exchange, Official Yearbook 1991-1992, at 23 (Stockton Press, 1992).

76. International Stock Exchange, Admission of Securities to Listing (Unwin Bros, Dec 1991).

77. FSA § 143(1); Yellow Book § 1, ch 1, ๆ 6.

78. Even if exempt from publication, certain limited information about a security must be given to the DTI, and in some cases, distributed to the public in brochure form. See Yellow Book $\$ 3$, ch 1 , Iๆ 5.3-5.4; Clive M. Schmitthoff, 1 Palmer's Company Law 305-06 (Stevens, 24th ed 1987). In brief, these exemptions apply to shares: (1) distributed to existing shareholders as a dividend, (2) distributed upon exchange of warrants or convertible debt securities (provided the company already has some outstanding shares listed, but not necessarily of the same class), (3) issued in exchange for outstanding shares of equal or greater nominal value, (4) that would increase a class of listed stock by less than $10 \%$, or (5) allotted to employees (provided there are already outstanding listed shares of that class).

79. Yellow Book $\$ 1$, ch 2 , ๆ 16 .

80. Id at $\$ 3$, ch 1, I 2.1 .

81. FSA $\S 144(2)$.

82. Although British regulation mainly addresses the truthfulness of disclosure, the Council also has authority to deny listing on the grounds that "the admission of the securities would be detrimental to the interests of investors." FSA $\S 144(3)(a)$. 
due in large part to the significant procedural constraints imposed upon private litigation in Britain. ${ }^{83}$

A significant force in assuring full disclosure is the issuing house. Admission to listing requires that a member of the Exchange sponsor the listing application of each security sought to be listed. ${ }^{84}$ This sponsoring member, usually the issuing house for the offering, investigates the issuer and communicates with the Exchange's Quotations Department while the application for listing is reviewed. As discussed below, the issuing house is typically the primary underwriter for the distribution, although there is no requirement that the sponsoring member participate in the distribution as issuing house or otherwise. ${ }^{85}$

\section{Structure and Timing of an Equity Offering}

Once the listing particulars is approved and the listing application is accepted, the issuer and the issuing house fix a price for the securities and usually announce the offer by publishing the listing particulars in the financial press. ${ }^{86}$ In a public offering, this is called "Impact Day." 87 The practice of publication stands in sharp contrast to U.S. requirements, which use delivery of a prospectus rather than media publication as the vehicle for informing the public.

There are several forms of offering. In all of them, the sponsoring member, acting as the issuing house, usually assumes market risk for a very short period of time. In a public offering, the issuing house may buy the securities outright from the issuer on Impact Day (as in a U.S. firm commitment offering), or it may enter into a standby agreement to purchase any shares that cannot be sold at the stated price. In either case, the issuing house typically passes off its entire risk to other financial institutions as "subunderwriters" who take a standby position in exchange for a fee. These arrangements are usually completed within a single day after Impact Day. ${ }^{88}$ The sub-underwriters do not market the securities they underwrite, as they are frequently institutional investors who often own securities for their own account. If required to purchase shares under the standby agreement, they may simply add the securities to existing inventory. ${ }^{89}$ After accepting the risk,

83. See quotation accompanying note 62 .

84. Yellow Book \& 1, ch 1, ๆा 3-5.

85. There is one other important twist to equity offerings in the United Kingdom. The Exchange requires listed companies to give their shareholders preemptive rights, a first option to buy any additional equities in proportion with their existing interests in the company. Most equity offerings therefore take the form of rights offerings to existing shareholders, often at discount of 10 $20 \%$ less than the market trading price. Shareholders may temporarily (for 15 months) waive this right, by a three-fourths majority vote. Companies Act $1985 \$ \S 89(1), 95$. See Poser, International Securities Regulation at 319 (cited in note 62).

3 .

86. The specific requirements for the form of publication are set forth in Yellow Book $\S 2$, ch 3, I

87. Wolfram \& Bennet, 1987 Colum Bus L Rev at 343 (cited in note 73).

88. Poser, International Securities Regulation at 307 (cited in note 62).

89. In such a case, the sub-underwriting fee becomes a rebate on the investor's purchase price. 
they may enter the secondary market to adjust their own positions in the securities during the subscription period. ${ }^{90}$

Following Impact Day, there is a two week delay as public investors subscribe for the shares. The issuing house and the issuer may seek to reduce the underwriters' risk through pre-offering publicity, which is legally permissible only if approved by the Exchange. ${ }^{91}$ But they are more likely to rely on the publication of listing particulars, combined with the "pre-emption discount" associated with a rights offering, to move the issue.92 The subscription period closes on "Application Day" and the shares are issued two days later, on "Allocation Day."

A variation on the public offering is the offer by tender. The issuer (through its issuing house) offers shares at a fixed minimum price. Members of the public submit bids ("tenders") at prices equal to or greater than the minimum. Once it has received the tenders, the issuer will designate a selling price, and all investors who tendered at this price or above will receive shares at this single price. As in a public offer, the issuing house agrees to purchase or to find purchasers for all shares at the minimum price, while passing off the risk to sub-underwriters who agree to stand by at the minimum price. ${ }^{93}$ The tender mechanism permits the market to fix the price, and is used when circumstances make the market's reaction to the issue unpredictable. ${ }^{94}$

The issuer and issuing house may also proceed by "placing" the securities rather than by public offering. A placing is roughly equivalent to a private offering in the United States. However, in equity placings valued over two million pounds, the Exchange requires that a minimum of twenty-five percent of the offering must either be made available to the public or distributed by another member of the Exchange that is independent of the sponsoring firm; furthermore, the value of a placing may not exceed fifteen million pounds if the applicant has no listed equity securities.95 Placings are not subunderwritten; rather, the issuing house rapidly distributes the securities to institutional investors on a permanent basis. Either the issuer or the issuing house may bear the risk that the securities cannot be placed during this period; that is, the placing may or may not be underwritten. One should note that use of the placing procedure does not remove the need to prepare a listing particulars, although its publication is not usually required. ${ }^{96}$

\section{Private Civil Liability}

Whenever the Yellow Book and the FSA require publication of a listing particulars, participants in the distribution who qualify as "responsible

90. Wolfram \& Bennet, 1987 Colum Bus L Rev at 347 (cited in note 73).

91. FSA $\S 154(1)$. See Schmitthoff, Palmer's Company Law at 314 (cited in note 78)

92. William A. Plapinger \& Richard C. Morrissey, U.S. and U.K. Underwriting Mechanics: A Comparison, 2:4 Insights 3, 4 (April 1988). See note 85.

93. See Geoffrey Morse, Charlesworth's Company Law 154, 171-72 (Stevens, 13th ed 1987).

94. See Poser, International Securities Regulation at 307-08 (cited in note 62).

95. Id at 306.

96. Yellow Book § 2, ch 3, ๆ 3.4 . 
persons" are exposed to liability under section 150 of the Act. Section 150 is not the exclusive remedy for investors. As discussed below, "private" investors may also recover under section 62 for any breach of DTI or SIB regulations, and SRO rules. Because no courts have entertained private civil claims by investors arising under the FSA, the following discussion is based on the statute's bare text, the Yellow Book, and judicial decisions which interpreted pre-FSA law.

1. Defective Disclosure in Listing Particulars. As noted above, persons who are "responsible" for listing particulars or supplementary listing particulars will be liable under section 150 for any misstatements or omissions in the filings. Each responsible person is liable for the documents' failure to reveal the information required to be provided by the general duty of disclosure in section 146 , or under the duty to provide updated information by way of supplementary listing particulars in section 147. The general duty under section 146 covers all disclosures called for by the Yellow Book, or that the Quotations Committee requests from the issuer. In addition, unlike U.S. rules, the disclosure obligation also includes all material information; the document must provide all information that an investor would reasonably require, and would expect to find in the listing particulars, in order to evaluate the offering.

Section 146 is not, however, the sole disclosure directive. Between the time when the listing particulars is approved and the time when the securities are sold, section 147 requires a supplementary disclosure of "significant" new information concerning matters discussed in the original listing particulars or "new matter[s]" whose disclosure would have been required in the initial filing. Thus, section 147 imposes upon responsible persons an affirmative duty to update the issuer's listing particulars. This duty continues until the securities have been sold.

a. Updating information before sale. The duty under section 147 to update the listing particulars after they have been filed encompasses "significant" new information, which relates either to a matter discussed in the original listing particulars or to a "new matter" whose disclosure would have been required in the initial filing. The addition of the word "significant" in defining the duty to provide updated information seems to add little to the definition of the general duty under section 146, which already requires disclosure of all material information.

Thus, for example, section 147 would require updated information to disclose a significant delay in the introduction of a new product whose prospects had been touted in the original listing particulars. And the company would be required to disclose a significant development concerning affairs that had not been featured in the listing particulars, such as a recent judicial ruling imposing substantial tort liability for defective design of a product already on the market; this fact would have been subject to disclosure in the initial filing if it had then been known. 
In comparison with U.S. standards for continuing disclosure, the requirements of section 147 seem moderately more strict. As discussed above, post-effective amendments to the U.S. registration statement are required for material information about the plan of distributing the securities, other than the price and related details. For registration statements that do not use Form S-3, and which thus do not continue automatically to accrete new information by reference upon the filing of each new Exchange Act report, amendment to include new reports is required before a sale may be completed only if the sale occurs nine months after the effective date, or when the old information has become more than sixteen months old, whichever is later.

b. Responsible persons. The responsible defendants are listed in section 152(1). The list includes the issuer, its directors, persons who accept responsibility for the listing particulars, and anyone else "who has authorized the contents ...."97 The scope of the last category is not fully clear, although section 152(8) states that persons do not become responsible for the particulars merely by "giving advice as to their contents in a professional capacity."98 Presumably, an expert who allows his statement of fact or opinion to be incorporated in the listing particulars has "authorized" that part of the document, although merely making a statement without consenting to its inclusion would not subject the expert to liability. ${ }^{99}$

In any event, persons who accept responsibility or authorize the contents of less than the full listing particulars will be liable only for their part of the statement. ${ }^{100}$ Thus, for example, it seems that a company's chief accounting officer might "authorize" the financial disclosures in the filing, although she would not be responsible for other aspects of the document such as market forecasts, analyses of mining surveys, or legal opinions on the validity of a proposed transaction.

At first glance, the word "underwriter" is conspicuously absent from the list of potentially responsible persons. However, a member of the Exchange must sponsor the listing application of each security sought to be listed. This member, which is usually (but not always) the issuing house, investigates the issuer and communicates with the Exchange's Quotations Department while the application for listing is reviewed. ${ }^{101}$ "The sponsoring firm must ensure that the Department is informed of all information which should be brought

97. FSA $\S 152(1)(e)$.

98. Thus, as in the United States, the giving of legal advice to the issuer or other participants does not make a lawyer liable to investors. In re ZZZZ Best Securities Litig., [1989] Fed Secur L Rptr (CCH) ๆ 94,485 (CD Cal 1989). See also note 57.

99. See Caparo Indus. plc v Dickman, [1990] 1 All ER 568 (HL) (Auditors are not liable to investors for negligence in preparing accounts; their duty runs to the shareholders as a group, for the purpose of helping them to make informed decisions in managing the company, but it does not extend to individual shareholders who may decide to trade in the company's securities).

100. FSA \& 152(3).

101. See notes 84-85 and accompanying text. 
to its notice."102 In this respect, the sponsoring member may have "authorized" the listing particulars's contents. ${ }^{103}$ Indeed, the sponsoring member would be potentially responsible even if it did not underwrite or participate in the offering as an issuing house.

Certainly, sub-underwriters who do not participate in preparing the listing particulars or in conducting the limited selling effort are not liable. Subunderwriters do not become involved in the distribution until after the listing particulars is published. ${ }^{104}$ Unless a sub-underwriter chose to accept responsibility in the listing particulars, it would not fall within any of the categories of responsible persons: the issuer itself, directors, those who accept responsibility, and those who "authorize" the contents of the document. ${ }^{105}$

Thus, unlike the U.S. system which deems all financial institutions accepting risk in the offering to be "underwriters" and therefore liable under section 11 unless they show due diligence, the British rules seem to place liability only upon that institution which actually conducts an investigation of the issuing company and "authorizes" the public disclosures. This functional approach seems more sensible and efficient than the American system, in which the managing underwriter conducts the entire investigation but carries only a fraction of the liability exposure under section 11 . Syndicate members who do not investigate the issuer remain liable under section 11 for their portions of the offering. To the extent that due diligence seeks to maximize detached investigation and disclosure of the issuer's condition for the benefit of investors, the U.S. system misallocates risks and rewards by allowing the investigative agent to avoid most of the liability. ${ }^{106}$

c. Is privity required? The section 150 cause of action benefits "any person who has acquired any of the securities in question" for injury "as a result" of defective disclosure. To a U.S. reader this language suggests a construction similar to section 11 of the Securities Act: The securities must be traceable to the specific disclosure document, and the loss must be causally related to the disclosure defect, but strict privity of contract is not required. ${ }^{107}$

As in the United States, the statute does not expressly require privity of contract; nor does it limit underwriters' liability to the price of the securities they offer to the public. ${ }^{108}$ But in ruling on a pre-FSA transaction, the court

102. Yellow Book § 1, ch 1, I 4 .

103. Moreover, $\$ 57$ requires all investment advertisements to be approved by an authorized person (such as a member of the Exchange like the issuing house). The statute defines investment advertisements as "any advertisement inviting persons to enter . . . into an investment agreement or to exercise any rights ... or containing information calculated to lead directly or indirectly to persons doing so." FSA $\$$ 57(2). Publication of listing particulars may be an investment advertisement that the issuing house must approve, and thereby "authorize," both the advertisement and the listing particulars itself.

104. See text accompanying note 88 .

105. See text accompanying note 97.

106. See Note, 53 Fordham L Rev at 1063 (cited in note 19).

107. See note 14 and accompanying text.

108. See note 19 and accompanying text. 
in Al-Nakib Investments (Jersey) Ltd. $v$. Longcroft ${ }^{109}$ denied recovery for the plaintiff's losses arising from his purchases of shares in the secondary market. The claim was based on negligent misrepresentations in a prospectus designed to promote a rights offering directly to existing shareholders. Even though the plaintiff had been an existing shareholder, and had relied upon the prospectus, the court found that the company owed no duty of care with respect to the plaintiff's secondary transactions that had not been directly promoted under the document. Thus, the court used concepts of causation and duty to impose a de facto privity requirement for recovery in negligence.

It remains to be seen whether the restrictive view of liability underlying $\mathrm{Al}$ Nakib will survive the enactment of the FSA. One could argue, based on section $151(5)$, that the statute does not require true reliance upon the alleged misstatements. Like sections 11 (a) ${ }^{110}$ and $12(2)^{111}$ of the Securities Act, FSA section 151(5) prevents recovery if the investor actually knew the truth of the matter misrepresented or omitted. This provision would be redundant if the court also required reliance upon the statement itself.

Further, it would be anomalous to allow an existing shareholder to recover for a rights offering when he did not know the listing particulars' contents, while an ignorant investor who subsequently purchased in the market, and thereby supported the market price from which rights offerings are typically discounted, cannot. Both investors rely on the market price and the marketplace's efficient assimilation of all publicly available information into that price datum, in deciding whether to buy. ${ }^{112}$ Therefore, a requirement of privity between plaintiff and defendant under section 150 seems unwarranted.

d. Reasonable investigation. There is no duty under sections 146 and 147 to disclose information which a person does not possess, "or which it would not be reasonable for him to obtain by making enquiries." 113 Because this language defines the defendant's initial duty of disclosure, it suggests that plaintiffs might bear the burden of showing that a defendant's investigation was inadequate. However, section 151(1) provides an affirmative defense allowing a responsible party to escape liability by showing that "he reasonably believed, having made such enquiries (if any) as were reasonable, that the statement was true and not misleading or that the matter whose omission caused the loss was properly omitted ...." (emphasis added). The wellestablished canon of construction, that particular language should override

109. [1990] 3 All ER 321 (Ch Div).

110. See note 16 and accompanying text.

111. See note 59 and accompanying text.

112. A fortiori, the statute should not require privity when a secondary purchaser in fact relied upon the listing particulars. To be sure, these arguments apply with equal strength to the U.S. rule requiring that securities be "traceable" to the particular registration statement in question, leaving other open market traders with no remedy for misrepresentations in the disclosure document. The fact that the U.S. statute strikes a balance between casting the defendant as a guarantor of the disclosure to the world and making him responsible solely in the face-to-face transaction does not make these arguments less persuasive.

113. FSA $\S 146(2)$. 
general provisions, would seem to govern the apparent conflict and place the burden of proof upon the defendant. ${ }^{14}$

Section 151(1) provides for broader grounds of defense than U.S. legislation in two important ways. First, in contrast with the Securities Act sections 11 and 12(2), which always require some investigation, ${ }^{15}$ the FSA language "if any" contemplates circumstances in which it may be reasonable to forego an investigation entirely. This distinction may not be entirely clear in practice, however, since courts applying the sliding scale approach to U.S. due diligence have sometimes approved the most cursory investigations. For example, the court in Laven $v$. Flanagan 116 approved as a reasonable investigation the reliance by "outside" directors, new in their positions, upon the uncorroborated (and erroneous) representations of management and independent auditors. In practice, Laven permits some defendants to escape liability without actively investigating.

Second, the British defense applies to all responsible persons. In contrast, the due diligence defense under section 11 is not available to the issuing company; in the United States the issuer is strictly liable for all material misrepresentations in the registration statement. In this respect the British rule is similar to the defense under section 12(2), which, unhappily for the U.S. issuer, does not shield against claims under section 11 and therefore provides full protection only when the offering is exempt from registration (or the statute of limitations for section 11 liability has expired). ${ }^{117}$

e. Expert statements. As in the United States, a responsible person may rely on the certification of an expert ${ }^{118}$ to shield himself from liability. The defense is broader under the FSA than under section 11 . Unlike the U.S. defendant, who must show that he "had no reason to believe and did not believe" that the expert's statement was untrue, ${ }^{119}$ the British defendant need not show that he believed the expert's statement was truthful. Rather, under the FSA he must establish merely that "he believed on reasonable grounds that the [expert] was competent to make or authorize the statement and had consented to its inclusion ...."120 Furthermore, the British issuer may also invoke the defense, along with its own reasonable investigation as discussed above, whereas a U.S. company is strictly liable.

114. As one court has phrased it:

[W] henever there is a particular enactment and a general enactment in the same statute, and the latter, taken in its most comprehensive sense, would overrule the former, the particular enactment must be operative, and the general enactment must be taken to affect only the other parts of the statute to which it may properly apply.

Williams v Inland Revenue Comm'rs, [1979] STC 598 (Ct App) (Bridge, J) (quotations omitted).

115. See note 26 and accompanying text.

116. 695 F Supp 800 (D NJ 1988) (applying $\S 11$ ).

117. See note 21 .

118. As in the United States, an expert is any person "whose profession, qualifications or experience give authority to a statement made by him." FSA $\$ 151(7)$. Compare note 21 and accompanying text.

119. See note 22 and accompanying text.

120. FSA § $151(2)$. 
There seems to be no sound reason for excusing a defendant on the basis of his reliance upon the certification of an expert if, at the time of submitting the listing particulars, the defendant was aware that the expert's statement was false. Surely the legislature would not have intended such an incongruous result. Therefore, British courts may interpret section $151(2)$ as being subject to a general requirement of good faith on the defendant's part, ${ }^{121}$ perhaps estopping a defendant from raising the defense when he has acted deceitfully.

2. Contravention of Rules and Regulations. If a defendant breaches any rule or regulation of the DTI, the SIB or an SRO, section 62 of the FSA allows recovery for a "private investor" 122 who suffers loss as a result; as defined by the SIB, a private investor is an individual who invests for his own account. ${ }^{123}$ The cause of action is "subject to the defenses and other incidents applying to actions for breach of statutory duty." 124 Thus, the plaintiff investor must show that the defendant's breach caused a loss that the rule was intended to prevent, and that the plaintiff belongs to the class of persons intended to be protected by the rule. ${ }^{125}$

The statute does not provide for direct recovery based on violations of the FSA's criminal antifraud provisions, ${ }^{126}$ although the rules and regulations may include the substance of these statutory provisions 127 and thereby confer a claim under section 62 . In particular, the statute specifically authorizes rules concerning stabilization and market-making practices, which would also confer upon private investors a statutory cause of action. ${ }^{128}$ Section 62 applies more generally to any SRO rules relating to a subject matter as to which the SIB has, or could have, promulgated its own rules.

No court has directly applied section $62 .{ }^{129}$ The courts may require proof of privity or direct reliance upon alleged misrepresentations in order to

121. As one British court has described the interpretive rule:

The prima facie rule is that words have their ordinary meaning. But that is subject to the qualification that if, giving words their ordinary meaning, we are faced with extraordinary results which cannot have been intended by Parliament, we then have to move on to a second stage in which we re-examine the words and see whether they must in all the circumstances have been intended by Parliament to have a different meaning or a more restricted meaning.

Swansea City Council v Heam, 23 HLR 284 (Ct App 1990) (quotation omitted).

122. FSA § 62A.

123. Financial Services Act 1986 (Restriction of Right of Action) Regulations 1991 (Statutory Instrument 1991 No 489). See Charles Abrams, Financial Services Update, 88 Law Society's Gazette 41 (May 29, 1991).

124. FSA $\S 62(1)$.

125. See Alan Berg, Section 62: The Full Extent of Exposure, Intl Fin L Rev 26, 26 (Aug 1988); Poser, International Securities Regulation at 295-96 (cited in note 62).

126. See FSA $\S 47$, discussed below.

127. See id at $\S 48(1)$.

128. Id at $\$ \S 48(2)(d), 48(2)(i)$.

129. The court in SIB v Pantell SA, [1991] 4 All ER 883 (Ch Div), stated in dictum that the statute gives no relief against a third party, such as a solicitor, who might be "knowingly concerned" with the contravention. In addition, it said that the statute provides "no right to claim an account of the profits made by the contravener." Id at 890 . 
establish legal causation of the plaintiff's loss, or her status as one of the persons intended to be protected by the regulation. This possibility, when combined with the limited class of potential plaintiffs ("private investors"), is likely to make section 62 relatively unimportant in practice.

3. Analysis of Private Liability Provisions. As noted at the outset of this discussion, popular attitudes toward private litigation and entrenched procedural obstacles may make private recovery under the FSA in British courts difficult, and prosecutions rare. Without definitive judicial construction, liability under section 150 appears modestly broader than Securities Act section 11 in one respect, modestly narrower in other ways, and uncertain in a few key areas.

The British rules appear to strike a compromise between the varying U.S. provisions discussed above. Except in an exempt transaction like a private placement, U.S. rules under Securities Act section 11 require the defendant in a registered offering to establish his own due diligence, his reliance upon the statement of an expert, or the lack of legal causation of the plaintiff's loss, ${ }^{130}$ in order to escape liability for any material misstatement in the registration statement. Plaintiffs usually need not show that they actually relied upon the alleged misstatements, ${ }^{131}$ and the class of potential defendants includes corporate officers and directors as well as the issuer and the underwriters. Privity of contract is unnecessary. ${ }^{132}$

In an exempt transaction, or when the plaintiff alleges a defect in new information that was disclosed by "sticker" on the old prospectus rather than by post-effective amendment of the registration statement itself, the plaintiff may recover under Securities Act section 12(2) (and Rule 10b-5) but not the more rigorous section $11 .{ }^{133}$ Section $12(2)$, unlike section 11 , requires the plaintiff to show a causal relation between the content of the defective disclosure document and the diminution in his securities' value or price, but does not require affirmative reliance upon the misstatements. The defendant may escape liability by showing a form of due diligence similar to section 11 . However, the class of potential defendants in a 12(2) suit is significantly smaller than under section 11: Only a "seller" who either transfers title to the securities or participates actively in the sale is liable. ${ }^{134}$ This is a modified form of privity, since the plaintiff must have dealt directly with the defendant.

a. Potential defendants: comparison. The group of potential defendants under FSA section 150 has not yet been authoritatively defined. Given its largest possible range, the section $152(1)$ category of responsible persons is slightly smaller than under section 11 , but significantly broader than section 12(2).

130. See note 18 and accompanying text.

131. See note 15 and accompanying text.

132. See note 14 and accompanying text.

133. See note 49 and accompanying text.

134. See note 56 and accompanying text. 
The British company's principal officers are not automatically responsible for the contents of the listing particulars, although they may have accepted responsibility or authorized part of the statement. Officers in the United States are automatically liable under section 11, absent proof of a defense, but can be liable under section 12(2) only if they actively participated in the primary distribution by communicating directly with investors.

British sub-underwriters are not responsible persons under section 150 , whereas their U.S. counterparts would be liable under section 11. Notably, U.S. underwriters are not liable under section 12(2) unless they actually communicate with the plaintiff through a prospectus or oral communication. ${ }^{135}$

The status of issuing houses is less certain. If the issuing house "authorizes" the listing particulars by sponsoring the application for listing, then it might become a responsible person. Assuming that this rule were correct, the British system would have avoided one criticism of U.S. due diligence practice: that risks and rewards are inefficiently distributed because the managing underwriter conducts the entire investigation for the benefit of investors but carries only a fraction of the liability exposure under section 11 .

b. Other issues. Substantial uncertainty clouds the issue of privity. Under U.S. principles, supported by the theory of informational efficiency in active securities markets, direct privity is not required. ${ }^{136}$ Prior British precedent suggests that privity may be necessary. If the old rule survives, section 150 will have a great deal less impact than section 11 (no privity required), and will approximate the functioning of section 12(2) (defendant must be a "seller").

The FSA provides a continuing duty to update all material information in the listing particulars. U.S. rules require post-effective amendment of the registration statement only for fundamentally important new information, and only when the initial filing has become outdated. Otherwise, new information must be disclosed only by "sticker" on the old prospectus. Although British securities lack the long shelf life of a delayed or continuous offering under SEC Securities Act Rule 415, public equity offerings usually entail two weeks of delay between Impact Day and Application Day. ${ }^{137}$

Finally, the range of affirmative defenses under British law is broader than under section 11 and section 12(2). Whatever the practical significance of the difference, the British statute departs from the U.S. tradition requiring an active investigation to support every non-expertised statement. ${ }^{138}$ Moreover, it allows issuers to invoke their own due diligence in public offerings, and not

135. See note $\mathbf{5 3}$ and accompanying text.

136. See text accompanying note 14 .

137. See text accompanying notes 93-94.

138. See text accompanying note 25 . 
only in private placements or other exempt transactions as under section 12(2). ${ }^{199}$

\section{E. Enforcement by Regulators}

The FSA provides a wealth of enforcement measures for regulators at various levels. In addition to the Crown's criminal remedies, the Secretary of State and the SIB under delegation may seek wide-ranging injunctive relief for violations of enumerated statutory provisions or rules thereunder. Further, regulators may sue for "restitution" on behalf of investors for violations of the same provisions. The substantive provisions of the act are equally broad, as discussed below.

1. Criminal Provisions. The logical beginning of the entire FSA scheme is its requirement in section 3 that no person engage in "investment business" without authorization by an SRO. This brings into play the concept of selfregulation underlying the institutional structure discussed above, and gives force to SRO disciplinary actions, such as suspension of SRO membership. Section 4 makes it a criminal offense, punishable by two years confinement, to violate section 3 .

Chapter $\mathrm{V}$ of the FSA regulates the conduct of investment business. For example, under FSA section 57 it is a criminal offense for a person who is not "authorized" to conduct investment business to publish an investment advertisement without the consent of an authorized person. Section 47 criminalizes the knowing or reckless making of a misleading statement, promise, or forecast in order to induce another person to enter (or refrain from entering) into an investment agreement. The defendant need not intend to cause this reliance; it is sufficient that he acted recklessly toward the other person's likelihood of relying upon the statement. ${ }^{140}$ Violation of section 47 carries a maximum prison term of seven years.

2. Civil Enforcement Procedures. Sections 6 and 61 of the FSA allow the SIB (under delegation from the Secretary of State) to seek civil remedies in judicial proceedings. Both provisions allow for injunctive relief and damages ("restitution awards") on behalf of investors injured by a violation of the Act or its rules, and both have been invoked in the courts.

Section 6 provides relief for investors who are injured by violations of the section 47 antifraud rules, or the non-criminal cold-calling prohibitions found in section 56. In furtherance of these investor protection remedies, the SIB may also obtain broad discovery privileges. The violator may be forced to account for any profits accrued as a result of its infraction and to pay any loss

139. See text accompanying note 61 .

140. FSA $\& 47(1)$. 
incurred by investors, or suffer the appointment of a receiver to collect such amounts. ${ }^{141}$

Section 61 overlaps the provisions of section 6 to a limited extent. As under section 6, the SIB may obtain accounting, damages and receivership remedies for violations of section 47 and 56, plus section 57 (prohibiting investment advertising by persons not authorized under section 3) and section 59 (prohibiting an authorized person from employing a person disqualified from the investment business). Moreover, the same remedies apply for violations of DTI and SIB rules and the regulations of an SRO or the Exchange. Broad discovery and injunctive relief are also available for enforcing these obligations. Thus, regulators may recover civil damages for investors from anyone who promotes an offering outside the officiallysanctioned structure of self-regulation.

As a creditor on behalf of investors, or in the public interest, the SIB may petition for the involuntary winding up of an offending company. ${ }^{142}$ The Board may also obtain so-called "Mareva" relief, seizing assets in Britain or abroad for the satisfaction of British investors' potential claims. ${ }^{143}$ A Mareva injunction is proper at the preliminary stage of the case even if the potential claims are merely "arguable." 144 This remedy has been called "one of the law's two nuclear weapons," 145 and its availability at the preliminary stage is a significant tool for the government. Indeed, the recent use of similar remedies by U.S. banking regulators has prompted concern over governmental abuse of power. ${ }^{146}$

Yet another example of the broad powers granted to regulators is In re $\mathrm{An}$ Inquiry Under the Companies Securities (Insider Dealing) Act 1985,147 in which a journalist was ordered to reveal his sources to DTI inspectors appointed under the FSA. The statutory scheme has further provisions for investigation and enforcement extending beyond the realm of primary distributions and beyond the scope of this article, but the provisions discussed above allow for more than adequate supervision of our field.

\section{IV}

\section{Conclusion}

It seems fair to say that the British system prefers collective enforcement by governmental bodies rather than individual enforcement by investors. This arrangement, backed in particular by the fee-shifting rules applied to unsuccessful private litigants, may provide for a more selective and

141. Section 6 also provides the same the accounting, damages, and receivership remedies for violations of $\S 3$, discussed above. In some circumstances, injunctive relief may be proper as well.

142. See In re DPR Futures Ltd, [1989] 1 WLR 778 (Ch Div).

143. SIB $v$ Vandersteen Associates $N V$, [1991] BCLC 206 (Ch Div).

144. SIB v Pantell $S A$, [1989] 2 All ER 673 (Ch Div).

145. See Anthony Marks \& William Rees, The Financial Services Acl and the Judges, 139 New LJ 1198 ,

1199 (Sept 8, 1989).

146. See, for example, Accountability by Sledgehammer, NY Times A24 col 1 (Mar 10, 1992).

147. [1988] 2 WLR 33 (HL). 
economical expenditure of litigation resources in pursuit of policy goals. In addition, by curtailing the role of investors as private attorneys general, the British scheme effectively reduces the influence of the courts and concurrently increases the importance of the regulatory authorities. Perhaps fearful of an overpowering central government agency, the British have adopted an institutional structure that diffuses power among the DTI, the SIB, SROs, and the Exchange.

The systemic values underlying the FSA scheme appear antithetical to U.S. values of individual self-determination and judicial ascendancy, but the potential cost savings that may result from the British experience deserve study by U.S. regulators. One can also hope that British courts construing the new statute will heed the principles of informational market efficiency that underlie many aspects of the U.S. scheme. 